\title{
Zjawisko mobilnych biur. Identyfikacja nowych przestrzeni pracy
}

\begin{abstract}
Nowadays we observe numerous changes in the field of employment. Possibility of flexible working hours, alternative job as being aligned to particular project, remote working and technology development results in a completely new perception of working time and space. More and more people adapt public spaces (third places) and private spaces (residences) to mobile professional activity, manifesting their freedom and ability to connect their responsibilities with leisure time. Interpretation of visual representations of mobile offices revealed by social media was the mode to find symptoms of consumption related to social status, people' relationship with objects and ways of arranging space to transform it into offices. Analysis of photographs revealed outdating category of non-place by Marc Ague. Work is closely related to mobile devices (laptops, tablets, phones) what enhances adapting to it also spaces that in the past were considered as non-individual (public transport, airports, train stations, waiting rooms). Also the function of third places (cafes, pubs, restaurants) is changing nowadays what effects in new forms of arranging space dedicated to individual work.
\end{abstract}

${ }^{1}$ Magda Prokopczuk, Instytut Filozofii i Socjologii, Wydział Stosowanych Nauk Społecznych, Akademia Pedagogiki Specjalnej im. Marii Grzegorzewskiej w Warszawie, Polska, magda.prokopczuk@gmail.com. 


\section{Keywords:}

mobile work, telework, third-place, non-place, Instagram

\section{UWARUNKOWANIA ZJAWISKA MOBILNYCH BIUR}

Piotr, właściciel firmy szkoleniowej, wchodzi do jednej z warszawskich kawiarni, od progu wypatrując wolnego stolika, blisko gniazdka z prądem. Siada, wyjmuje swojego srebrnego MacBooka i teczkę z papierami. Zamawia duże latte i kawałek ciasta marchewkowego. Bierze do ręki telefon komórkowy i robi zdjęcie przedmiotów ułożonych na pulpicie swojego stolika. Przysuwa kawę bliżej krawędzi swojego komputera tak, aby zmieściła się w kadrze. Mija chwila, zanim odkłada telefon i rozpoczyna pracę. Poznań Główny. Tosia wyjmuje z kieszeni telefon, aby sprawdzić, w którym wagonie pociągu ma zarezerwowane miejsce. Wchodzi najbliższymi drzwiami i siada. Wyjmuje komputer i pyta konduktora o hasło do wi fi. Pragnie utrwalić swoją kolejną podróż w delegację. Chwyta telefon i odchylając się w bok robi zdjęcie komputera na tle przesuwającego się za oknem krajobrazu. Krakowska kamienica. Ewa bierze dziś home office. Ścieli łóżko i zakłada żakiet, ponieważ za chwilę ma rozpocząć konferencję na Skype z zagranicznymi klientami. Przeciera ścierką nocny stolik, kładzie laptopa i robi zdjęcie swojego nowo zaaranżowanego biura. Udostępnia fotografię na swoim profilu na Instagramie, dodając hashtag \#mobilnebiuro.

Powyższe historie, choć zostały zmyślone, stanowią ilustrację współczesnych przemian zachodzących w sferach pracy. Dotychczas o mobilnej pracy badacze pisali głównie z perspektywy przemian zachodzących w formach zatrudnienia, tj. upowszechnienia się tzw. telepracy, czyli pracy na odległość i konsekwencji idących za tego typu świadczeniem pracy. Jak pisze Magdalena Szpunar, „praca biurowa w warunkach sztywnego czasu pracy, stałych miejsc, scentralizowanych struktur przedsiębiorstw będzie stopniowo przekształcać się w pracę elastyczną ze względu na czas, miejsce i formę przedsiębiorstw, tworząc nowe możliwości pracy” (Szpunar, 2007). Oderwanie się pracy od miejsca sprzyja adoptowaniu przestrzeni publicznych jako miejsc mobilnej aktywności zawodowej. W tak zarysowanym pejzażu zarówno ławka w parku, stolik w kawiarni, siedzenie w autobusie, poczekalnia w urzędzie, jak i sala odlotów i przylotów stają się nowymi przestrzeniami pracy. Jeżeli tylko mamy podłączenie do Internetu bezprzewodowego, dostęp do prądu i miejsce, przy którym można usiąść, możliwa jest praca wszędzie.

Jak pisze Małgorzata Dymnicka (2011) za Rayem Hudsonem (2001): „miejsca są wytwarzane przez wielokrotnie podejmowane czynności. Rozwój rozmaitych 
globalnych mobilności - zarówno zewnętrznych, jak i wewnętrznych - stanowi o końcu miejsca nazwanego i początku miejsca niezdefiniowanego” (Dymnicka: 2011). To oderwanie pracy od miejsca powoduje redefinicję wielu przestrzeni, począwszy od tych, których pierwotną funkcją był odpoczynek czy rozrywka (np. kawiarnie), poprzez przestrzenie otwarte znajdujące się na świeżym powietrzu, skończywszy chociażby na nie-miejscach (Ague, 2010), które z definicji są przestrzeniami pozbawionymi „emocjonalnych kotwic”, w których praktycznie nie chce się przebywać. Współcześnie możemy zaobserwować przemiany przestrzeni, prowadzące ku kumulowaniu wielu sfer aktywności jednostek w jednym miejscu, takim, które jest wielofunkcyjne i wielozmysłowe zarazem (Szlendak, 2011b).

Dostrzeżenie faktu zachodzących zmian implikuje postawienie na nowo pytania o definicję trzecich miejsc (Oldengurg, 1998). Według amerykańskiego socjologa Raya Oldenburga trzecie miejsca to przestrzenie publiczne, w których jednostki dobrowolnie, nieskrępowanie, nieformalnie spędzają swój czas wolny, oddając się szerokorozumianemu odpoczynkowi i rozrywce. Co najważniejsze, są to miejsca oddzielone od sfer prywatnych (domu) i sfer zawodowych (pracy), które Ray Oldenburg nazywa kolejno pierwszymi i drugimi miejscami. Dwie dekady po ukazaniu się książki „The Great Good Places”, w której zaprezentowana została owa koncepcja, można zastanawiać się nad jej aktualnością i zastosowaniem jako kategorii analitycznej dla współczesnych badaczy.

Jak pisze Maciej Frąckowiak (2014), „przestrzeń przestaje być jedynie czymś, na co znajdujemy czas po pracy lub co mijamy w drodze do niej. Jeśli mamy przy sobie komputer, możemy usiąść praktycznie gdziekolwiek i popracować [...]. Postępujące oderwanie pracy od konkretnego miejsca i czasu sprawia, że przestrzeń publiczna staje się - jak to określa Nicola Millard - miejscem trzecim”. W definicji Nicoli Millard trzecie miejsca nie są wyłącznie tymi, w których spędzamy czas wolny na zabawie czy rozrywce, ale stają się „czymś pośrednim pomiędzy pracą w biurze, a pracą w domu” (Frąckowiak, 2014), czymś, co współcześnie coraz częściej zyskuje miano office.

Ze względu na fakt, że coraz trudniej jest wyodrębnić granice przebiegające pomiędzy przestrzeniami działań jednostek, tym samym niejednoznaczna staje się kategoria trzeciego miejsca. Jedynie słuszne wydaje się traktować je jako „coś pomiędzy”, jako przestrzenie, w których mieszają się różne sfery aktywności, w których urzeczywistnia się utopia synergii obowiązków i przyjemności. Tym samym, kawiarnia staje się wielofunkcyjnym miejscem przekształcającym się w zależności od potrzeb jednostki w miejsce spotkań, instytucję kultury (Mancwel, 2013), centrum aktywności lokalnej czy omawianym w niniejszym artykule biurem. 
Ważnym czynnikiem sprzyjającym adoptowaniu trzecich miejsc jako przestrzeni mobilnej aktywności zawodowej jest również ich społeczny charakter, który można wyrazić stwierdzeniem „bycia wśród innych”. Rozwój metropolii zwiastuje pojawienie się nowych aktorów społecznych: mobilnej klasy kreatywnej (Florida, 2005), klasy metropolitarnej (Jałowiecki, 1998), „mejkerów” charakteryzujących się „odejściem od zestandaryzowanych wzorców i rutyny” (Lange, 2014). To oni w głównej mierze stają się pracownikami mobilnymi, poszukującymi w przestrzeniach społecznych „podobnych innych”, wśród których przebywanie nada iluzję przynależności, wspólnotowości, reprezentowania podobnych interesów.

W niniejszym artykule pragnę zaprezentować wyniki analizy wizualnych reprezentacji przestrzeni zamieszczanych przez użytkowników portalu Instagram, których celem było poszukiwanie odpowiedzi na pytania: jakiego typu przestrzenie adaptowane są przez jednostki do mobilnej aktywności zawodowej oraz czy ich użytkownicy podtrzymują definicje tych miejsc, czy starają się ją przeformułowywać. Nim przejdę do ich prezentacji, pragnę poświęcić kilka słów na omówienie specyfiki portalu Instagram i tworzonych przez samych użytkowników baz danych, które mogą posłużyć za „gotowy” materiał do analizy dla badaczy społecznych.

\section{WIRTUALNE „BAZY DANYCH”}

Portal Instagram to najpopularniejsza aplikacja do publikowania i rozpowszechniania zdjęć. Choć ów portal nieczęsto zyskuje zainteresowanie badaczy społecznych, bez wątpienia zasługuje na uwagę. Bowiem można traktować zamieszczane w nim fotografie, jako dokumentację życia codziennego osób młodych.

Według Megapanelu PBI/Gemius (2015) polskich użytkowników portalu jest ok. 3,2 mln, przy czym najczęściej użytkownikami Instagrama są osoby młode w wieku 18-34 lata (ok. 60\%)². Choć trudno wskazać dokładnie, ile fotografii publikują polscy internauci, na świecie tendencja plasuje się na poziomie ok. $60 \mathrm{mln}$ zdjęć dziennie. Pojawia się w takim razie pytanie, jak wybrać z wielu milionów fotografii te obrazy, które z punktu widzenia badań społecznych będą użyteczne?

Pomocne okazują się być hashtagi, czyli znaczniki nadawane przez użytkowników podczas publikowania zdjęcia w celu określenia kategorii tematycznej, którą ma reprezentować dana fotografia. Ma to głównie na celu porządkowanie

2 Dane z portalu Facebook, udostępnione na stronie: http://www.wirtualnemedia.pl/artykul/3-2-mln-polskich-uzytkownikow-instagrama-przewazaja-kobiety-i-nastolatki-top50-uzytkownikow [29.11.2016]. 
publikowanych treści. W ten sposób powstaje tysiące baz danych złożonych z obrazów, ukazujących różne reprezentacje danej kategorii. Ukróca to tym samym czas spędzony przez badacza na tworzeniu ich samodzielnie oraz wyklucza ryzyko przeoczeń, wybiórczości w ich tworzeniu.

Oczywiście, są również ograniczenia i trudności w korzystaniu z tego rodzaju „baz danych”, które skrótowo postaram się wskazać. Pierwszym problemem jest selektywność tego rodzaju materiałów, czyli dostarczanie niedostatecznie pełnych informacji na temat badanej rzeczywistości. Przykładowo, trudno zidentyfikować motywacje towarzyszące różnym przedstawieniom, emocje, jednostkowe czy egalitarne doświadczenia. Drugą trudnością jest dobranie odpowiednich wskaźników do ich analizy, aby wykluczyć zjawisko nadinterpretacji faktów. Mamy do czynienia z ograniczonym kontekstem, w którym jedyne informacje czerpane są z obrazów i (nieobligatoryjnie) opisów im towarzyszącym. Po trzecie istnieje problem doboru próby do badania, zarówno w obrębie poszczególnych kategorii, jak i ich reprezentacji. Choć owe ograniczenia w badaniu wirtualnych baz danych można by było zapewne mnożyć, to z pewnością korzystanie z nich zasługuje na uwagę, bowiem ukazują nieuchwytną, prywatną codzienność, będącą często w kręgu zainteresowań badaczy, lecz do niedawna dla nich niedostępną.

\section{REPREZENTACJE MOBILNYCH PRZESTRZENI PRACY}

W celu identyfikacji różnych typów przestrzeni adaptowanych jako miejsca aktywności zawodowej, zdecydowałam się na przeprowadzenie analizy fotografii zamieszczanych przez użytkowników portalu Instagram pod hashtagami \#mobilnebiuro, \#pracazdalna. Łącznie analizie poddanych zostało blisko 400 fotografii zamieszczanych od 2013 roku. Wybór takich kategorii głównie determinowany był chęcią analizy wyłącznie fotografii zamieszczanych przez polskich użytkowników ${ }^{3}$, ukazujących różne reprezentacje swoich mobilnych przestrzeni pracy.

Można wyróżnić sześć typów przestrzeni prezentowanych przez użytkowników portalu jako mobilne biuro: (1) przestrzenie prywatne (dom, mieszkanie, ogródek, taras), (2) lokale gastronomiczne (kawiarnie, restauracje, puby, bary), (3) otwarta przestrzeń publiczna, tzw. „na powietrzu” (plaże, parki, łąki, bulwary), (4) zamknięte przestrzenie publiczne, „w budynku” (instytucje kultury, galerie

3 Najczęściej na portalu Instagram używa się anglojęzycznych hashtagów, tak aby fotografie trafiały do jak najszerszego grona odbiorców. Przykładowo hashtag \#mobileoffice zawiera ponad 50 tysięcy postów. 
handlowe), (5) co-working space (specjalne przestrzenie do wynajmu biurek) oraz (6) nie-miejsca (lotniska, dworce, środki transportu, poczekalnie, przestrzenie pozbawione).

Większość prezentacji w obrębie wyszczególnionych powyżej kategorii łączy kilka cech. Po pierwsze standaryzacja i powtarzalność kadru. Fotografie są podobne do siebie zarówno ze względu na przedmiot przedstawienia, jak również ułożenie obiektów w kadrze. Na pierwszym planie zazwyczaj ukazywane są narzędzia pracy, przedmioty wykorzystywane podczas aktywności zawodowej. Często są to urządzenia mobilne (laptop, tablet, smartfon), notes, kalendarz, rzadziej książki. Zajmują one znaczny obszar kadru i ułożone są w zależności od tego, co ma być najważniejszym akcentem przedstawienia: przedmiot czy przestrzeń, w której wykonywana jest fotografia. Obok narzędzi pracy, nieodzownym elementem prezentacji jest kubek lub filiżanka (od standardowych naczyń po papierowe kubki „na wynos” znanych sieci kawiarni). Owe przedmioty obecne są praktycznie w każdym typie przestrzeni, od trzecich miejsc po otwarte przestrzenie publiczne.

Przedmioty odgrywają w mobilnej pracy znaczącą rolę, stają się atrybutami pracy ich użytkowników. Jak podkreśla Małgorzata Dymnicka (2013) „istotne znaczenie w nurcie socjologii mobilności mają przedmioty. Dzięki ich obecności przestrzeń może się przekształcić w miejsce”. I tak na przykład, nie-miejsca, stają się „oswajane” przez ich bywalców, poprzez włączanie w ich obszar przedmiotów.

W zależności od typu przestrzeni inaczej kadrowane jest łło. Czym bardziej „atrakcyjne” wydaje się być miejsce, w którym wykonywana została fotografia, tym szerzej ukazuje się je w kadrze. „Atrakcyjne” miejsce rozumiane jest tu jako prezentacja najbardziej niecodziennych, nietypowych przestrzeni na pracę lub najbardziej modnych czy innowacyjnych. Przykładem może być plaża, egzotyczna sceneria podczas delegacji, popularna kawiarnia, innowacyjna przestrzeń co-workingowa, miejsca „ekstremalne” (np. usytuowane na wysokości) lub z widokiem na symbole danej metropolii (np. Pałacu Kultury w Warszawie).

Rzadko natomiast ukazywani są na fotografiach sami użytkownicy mobilnych przestrzeni. Zależy to oczywiście od kilku czynników. Po pierwsze od tego, czy praca wykonywana jest w samotności, czy w obecności innych osób, znajomych, którzy mogliby zrobić zdjęcie, następnie od wspomnianej powyżej scenerii, która mogłaby skłaniać do afirmacji na jej tle.

Kolejną cechą wspólną prezentacji jest ich estetyka. Dzięki aplikacji Instagram niezwykle łatwa i prosta staje się obróbka zdjęć. Każdy użytkownik ma do wyboru przybornik, z którego może wybrać gotowy filtr, by nadać fotografii lepszy efekt. 
Dzięki tej usłudze, fotografie prezentujące mobilne przestrzenie wydają się być profesjonalne, a przedmioty i scenerie, które ukazują - nowoczesne i modne.

Warto podkreślić, że publikowane na Instagramie fotografie ukazujące mobilne miejsca pracy są bardzo często inscenizowane. Skrupulatna aranżacja przestrzeni, często nieprzypadkowej, świadomie wystylizowanej nie tylko dla wygody ich użytkowników, ale również (może i przede wszystkim) na potrzebę wykonania fotografii, która zyska aprobatę użytkowników obserwujących dany profil, to kolejny aspekt charakteryzujący opisywane zjawisko.

\section{ZAKOŃCZENIE}

Fotografie publikowane przez użytkowników portalu Instagram ukazują walory nowej kultury pracy. Ze względu na charakter aplikacji, obrazy są zazwyczaj utrzymywane w charakterze afirmującym ten styl aktywności zawodowej, nie pokazując negatywnych konsekwencji płynących z tego rodzaju świadczenia pracy, do których między innymi należy zacieranie się granic pomiędzy różnymi sferami życia jednostek, niepewność, brak stałości. Adaptowanie różnorodnych typów przestrzeni do mobilnej pracy wpływa na przeformułowywanie ich definicji. Ulegają zmianie pierwotnie nadawane znaczenia i funkcje miejsc lub nie-miejsc. Pytanie, którego odpowiedzi należy poszukiwać, dotyczy konsekwencji ekspansji mobilnych pracowników dla szerokorozumianej przestrzeni zarówno tej prywatnej, jak również publicznej.

\section{Literatura:}

Augé, M. (2011). Nie-miejsca: wprowadzenie do antropologii hipernowoczesności. Warszawa: Wydawnictwo Naukowe PWN.

Błaszczyk, M. (2013). W poszukiwaniu socjologicznej teorii miast. Meandry ekonomii politycznej. Warszawa: Wydawnictwo Naukowe Scholar.

Burszta, W. (red.), (2010). Kultura miejska w Polsce z perspektywy interdyscyplinarnych badań jakościowych. Warszawa: Narodowe Centrum Kultury.

Dymnicka, M. (2011). Od miejsca do nie-miejsca. Folia Sociologica, nr 36/2011, s. 35-52.

Dymnicka, M. (2013). Przestrzeń publiczna a przemiany miasta. Warszawa: Wydawnictwo Naukowe Scholar.

Florida, R. (2010). Narodziny klasy kreatywnej. Warszawa: Narodowe Centrum Kultury. Kubicki, P. (2011). Nowi mieszczanie - nowi aktorzy na miejskiej scenie. Przegląd Socjologiczny, t. LX, nr 2-3, s. 203-227.

Krajewski, M. (red.). (2012). Niewidzialne miasto. Warszawa: Fundacja Bęc Zmiana. 
Kusiak, J., Kacperski, W. (2013). Kioski z wódką i demokracją. Historia polityczna warszawskich „kawiarni obywatelskich” jako miejsc kształtowania się nowych ruchów miejskich i reprodukcji podziałów społecznych. Kultura i Społeczeństwo, nr 2, s. 67-89.

Lorens, A. (2014). Fenomen miejsc biesiadnych w mieście. Kultura popularna i kultura wysoka przy jednym stole. Warszawa: Fundacja im. Stefana Kuryłowicza.

Mancwel, J. (red.), (2013). Kawiarnie Kultury. Diagnoza. Raport z badań Pracowni badań i innowacji społecznych „Stocznia”. Pobrane z: http://www.stocznia.org.pl/www/ images/pliki_do_podczepienia/raporty_publikacje/ Kawiarnie_Kultury._Raport.pdf.

Oldenburg, R. (1998). The Great Good Place: Cafes, Coffee Shops, Community Centers, Beauty Parlors, General Stores, Bars, Hangouts, and How They Get You Through the Day. New York: Paragon House.

Szlendak, T. (2010a). Aktywność kulturalna. W: W. Burszta (red.), Kultura miejska w Polsce z perspektywy interdyscyplinarnych badań jakościowych. Warszawa: Narodowe Centrum Kultury.

Szlendak, T.(2010b). Wielozmysłowa kultura iwentu. Skąd się wzięła, czym się objawia i jak w jej ramach oceniać dobra kultury? Kultura Współczesna, nr 4 (66), s. 92-109. Szpunar, M. (2007). Telepraca jako nowa forma zatrudnienia. Pobrane z: http://www.magdalenaszpunar.com/_publikacje/2007/telepraca_jako_nowa_forma_zatrudnienia.htm. Świątkowska, B. (red.), (2014). My i oni. Przestrzenie wspólne. Projektowanie dla wspólnoty. Warszawa: Fundacja Bęc Zmiana. 
